\title{
Helbred og trivsel
}

\author{
Artikel 5 \\ PETER LA COUR \& HEIDI FRØLUND PEDERSEN
}

ENGLISH ABSTRACT: During the first COVID-19 lockdown, public health officials and political decision makers were aware that the lockdown would have some sort of psychological repercussion, but it was totally unknown what reactions the disease would evoke. This article investigates how the physical and mental health (well-being) were affected. Data from the COVID-19 survey indicate that negative consequences were uneven distributed in the population with especially young women, but also young men reporting alarming degrees of low well-being.

DANSK RESUMÉ: Gennem første COVID-19 nedlukning i foråret 2020 var det endnu helt ukendt, hvilke reaktioner sygdommen ville fremkalde. Denne artikel undersøger, hvordan det fysiske og psykiske helbred (trivslen) blev påvirket. Den fremhæver, hvordan især de negative påvirkninger ramte befolkningen skævt, og at særligt de unge kvinder, men også unge mænd rapporterede mistrivsel $i$ alarmerende omfang.

KEY WORDS: Covid-19; Health; Well-Being in Denmark

COVID-19-krisen har formentlig personligt påvirket alle på den ene eller anden måde. Da det første datasæt, som denne artikel og dette særnummer behandler, blev indsamlet i perioden 8-23. maj 2020, var det endnu helt åbent, hvad konsekvenserne af første Corona-nedlukning ville blive, og hvordan de ville kunne måles. Som angivet i dette nummers artikel 3 "COVID-19-krisen. Forløb og bekymringer" var dette fase præget af alvorlige helbredsbekymringer, hvorfor det i spørgeskemaudarbejdelsen forekom nærliggende at inkludere spørgsmål, der angik helbred og generel trivsel. Denne interesse var endvidere ansporet og forstærket af de mangeartede og tætte relationer mellem religion og helbred, især psykisk helbred og trivsel (wellbeing), som i de seneste år er blevet påvist og udforsket (jf. Koenig et al. 2012). Derfor indeholder denne undersøgelses første spørgerunde fire spørgsmål knyttet til helbred og trivsel: (1) faktisk Corona-sygdom; (2) bekymringer over, om man selv eller andre kan blive smittet; (3) selvvurderet fysisk helbred; og (4) det mentale velbefindende. Spørgsmålene om faktisk Coronasygdom og om smittebekymring er udviklet specifikt til denne 
undersøgelse, mens de to sidste helbredsmål er standardiserede screeningsspørgsmål, der kan sammenlignes med andre nyere undersøgelser, hvor de samme spørgsmål er stillet på samme måde.

Dette kapitel handler om de fire spørgsmål, dvs. det generelle helbred og den generelle trivsel i begyndelsen af genåbningen efter den store nedlukning i foråret 2020. Undersøgelsens respondenter havde i svarperioden stadig den første nedlukning frisk i erindring, og størstedelen af nedlukningen var stadig gældende. Men der var også tegn på, at krisen ville drive over og en tro på, at tingene igen ville vende tilbage til normale forhold meget snart, syntes at vokse frem. Man kendte dengang intet til de senere stramninger, der ville vise sig nødvendige i sensommeren og efteråret 2020.

\section{Faktisk Corona-sygdom}

COVID-19 var på undersøgelsestidspunktet stadig en meget sjælden sygdom, og formodninger om, at krisen ville bringe faktisk sygdom og død tættere på danskerne, kom slet ikke til at holde stik på dette tidspunkt. Der var således ingen af undersøgelsens 1540 respondenter, der selv havde været indlagt med COVID-19, og kun 5 personer (0.3 procent) angav at have været "temmeligt syge" med COVID-19. 18 personer (1,2 procent) angav at have været testet positive uden at have været særlig syge. Kun 1 person havde haft et medlem af husstanden, der havde været indlagt. Disse tal er så små, at det ikke er muligt at lave meningsfuld statistik på dem.

\section{Bekymring for at blive smittet}

Bekymringen for smitte blev vurderet med spørgsmålet: "Hvor enig eller uenig er du udsagnet: Jeg er bekymret over at jeg selv eller andre skal blive smittet med Corona?", og svarmulighederne var "stærkt uenig, uenig, noget enig, enig, stærkt enig." (Tab. 5.1).

Tabel 5.1. Frygt for smitte. Procent

\begin{tabular}{l|ccc}
\hline \multicolumn{2}{c}{ Alle } & Kvinder & Mænd \\
\hline Stærkt uenig & $6 \%$ & $4 \%$ & $8 \%$ \\
Uenig & $14 \%$ & $11 \%$ & $17 \%$ \\
Noget uenig & $15 \%$ & $14 \%$ & $16 \%$ \\
Noget enig & $30 \%$ & $32 \%$ & $29 \%$ \\
Enig & $22 \%$ & $24 \%$ & $21 \%$ \\
Stærkt enig & $12 \%$ & $16 \%$ & $9 \%$ \\
\hline
\end{tabular}

Som det kan udledes fra tabellen, angiver ca. 35 procent, at de ikke er personligt bekymrede over smitten i sig selv, mens majoriteten på ca. 65 procent angiver, at de er mere eller mindre bekymrede. Smittefaren synes således også til at være blevet til et personligt anliggende for ca. 2/3 af befolkningen. Der er klare kønsforskelle i bekymringerne ( $\chi^{2}$-test på tabellen angiver $\left.\mathrm{p} \leq .001\right)$. Der synes især at være forskelle mellem kønnene i skalaens yderpunkter, dobbelt så mange mænd som kvinder er "stærkt 
uenige" i at være bekymrede, dvs. at de slet ikke er bekymrede, mens næsten dobbelt så mange kvinder som mænd er "stærkt enige" i at være bekymrede. Ser man på aldersfordelingen, ses en klar sammenhæng mellem alder og bekymring. Smittebekymringen er forholdsvis mindre til stede i ungdommen, mens den stiger for alderen 45+ og synes temmelig stor i alderen 65+. Dette følger ganske myndighedernes angivelser om, at især de ældre kan udvikle komplicerede sygdomstilfælde og muligvis dø af sygdommen. Korrelationen ( $r)$ mellem alder og smittefrygt er $0.2(p<.001)$, og kan ses på figur 5.2.

Figur 5.2. Smittefrygt og alder

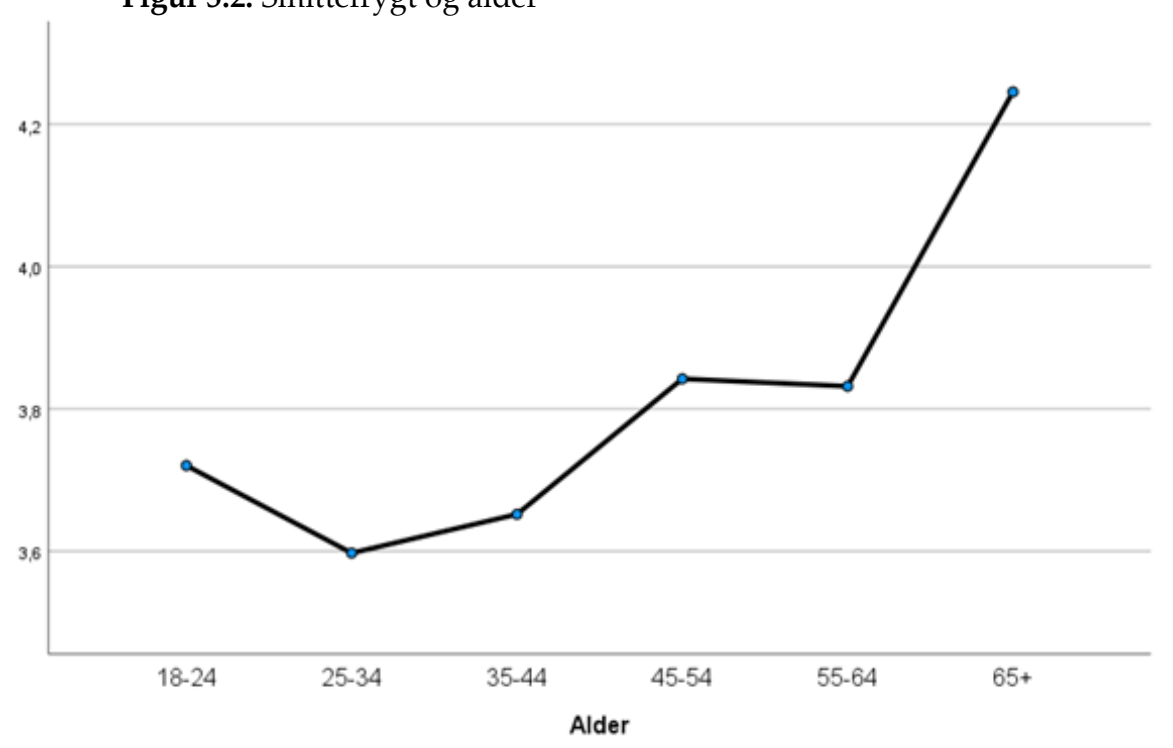

\section{Selvvurderet helbred}

"Selvvurderet helbred" er et enkelt, standardiseret screeningsspørgsmål, der bl.a. benyttes i Sundhedsstyrelsens undersøgelser over danskernes sundhed (Sundhedsstyrelsen 2017). Spørgsmålet lyder: "Hvordan vil du beskrive dit nuværende helbred: Meget godt, godt, nogenlunde, dårligt, meget dårligt." Spørgsmålet har vist sig at være entydigt og nemt at have med at gøre, og det er anvendt $i$ utallige store undersøgelser på befolkningsniveau. Spørgsmålet har også vist sig at være en af de stærkeste prædiktorer for både sygelighed og dødelighed; jo dårligere en person vurderer sit eget helbred, desto større er risikoen for faktisk sygelighed og død. Vi har valgt at sammenligne tallene fra denne undersøgelse med tallene fra undersøgelsen "Danskernes værdier", indsamlet i 2017. Her blev samme spørgsmålet stillet, men hvor det var spørgsmål om tro og holdninger, der var undersøgelsens hovedformål, og spørgsmålets kontekst derfor kan siges at være nogenlunde enslydende (Tab. 5.3). 
Tabel 5.3. Selvvurderet helbred. Hvordan vil du beskrive dit nuværende helbred? Procent

\begin{tabular}{l|cc}
\hline \multicolumn{1}{c}{} & Denne undersøgelse & Værdiundersøgelsen 2017 \\
\hline Meget godt & $28 \%$ & $33 \%$ \\
Godt & $44 \%$ & $39 \%$ \\
Nogenlunde & $21 \%$ & $20 \%$ \\
Dårligt & $5 \%$ & $6 \%$ \\
Meget dårligt & $15 \%$ & $1 \%$ \\
\hline
\end{tabular}

Som det umiddelbart ses, er der ikke de store forskelle i tallene, bortset fra, at der er en mindre del, der i denne undersøgelse erklærer, at de har det "meget godt", og flere, der har det "godt". Forskellen er imidlertid lille og ikke statistisk signifikant (t-test). Respondenterne synes således ikke generelt påvirket af Coronasituationen på deres fysiske helbred på undersøgelsestidspunktet.

\section{WHO5}

"WHO5" er et dansk udviklet screeningsskema vedrørende mental trivsel, der også anvendes i flere store undersøgelser. Man skal svare på, om man inden for de sidste 2 uger "a. har været glad og i godt humør; b. har jeg følt mig roligt og afslappet; c. har jeg følt mig aktiv og energisk; d. er jeg vågnet frisk og udhvilet; e. har min dagligdag været fyldt med ting, der interesserer mig." Spørgsmålene skal alle besvares med kategorierne: Hele tiden/det meste af tiden/ lidt mere end halvdelen af tiden/lidt mindre end halvdelen af tiden/lidt af tiden. Svarene scores fra 5-0 og summen ganges med fire, hvilket slutteligt giver en skala fra 0 til 100, hvor 100 angiver størst mulig trivsel. Ud fra danske undersøgelser og normalfordelinger har Sundhedsstyrelsen angivet normer og såkaldte cut-off værdier ved skemaet (Sundhedsstyrelsen, udateret). Det danske gennemsnit for befolkningen som helhed er 68 point, hvilket fordeler sig en lille smule ujævnt over kønnene, kvinder 67, mænd 69. De 16-20-årige angives typisk at score lidt lavere end de 20-80-årige, personer over 80 år scorer generelt lavest. Når WHO5 anvendes som screeningsinstrument, angives det af Sundhedsstyrelsen, at pointtal over 50 ikke umiddelbart angiver risiko for depression eller langvarig stressbelastning. Ved pointtal mellem 36-50 angives der, at der kan være risiko for depression eller stressbelastning. Ved pointtal mellem 0-35 angives det, at der kan være stor risiko for depression eller stressbelastning.

I denne undersøgelse er gennemsnittet i WHO5 62,4 point. Det er 8,2 procent lavere end det, som er angivet som gennemsnittet i Danmark i en tid uden Corona. Der er ikke opgivet standarddeviation og $\mathrm{N}$ i Sundhedsstyrelsens publikationer, så egentlig signifikans af denne forskel kan ikke beregnes. Forskellen må ikke desto mindre antages at være betydelig. Det er sandsynligt, at danskernes trivsel i perioden lige efter den store nedlukning er blevet væsentligt negativt påvirket. Denne antagelse underbygges i det følgende, hvor fordelinger foldes ud. Kvinderne synes væsentligt 
mere påvirkede end mændene. Nedgangen i point i forhold til normen er gennemsnitligt 6,5 point for kvinderne og 4,7 point for mændene (Tab. 5.4).

Tabel 5.4. WHO5 score fordelt på køn

\begin{tabular}{lll}
\hline & Denne undersøgelse & Sundhedsstyrelsens normer \\
\hline Kvinder & 60,5 & 67 \\
Mænd & 64,3 & 69 \\
\hline
\end{tabular}

Også aldersfordelingen viser tydelige forskelle mellem de forskellige aldersgrupper. Der ses den helt entydige sammenhæng, at jo lavere alder, desto mindre trives man, som det ses i figur 5.5.

Figur 5.5. Sammenhæng mellem aldersgrupper og trivselsscore

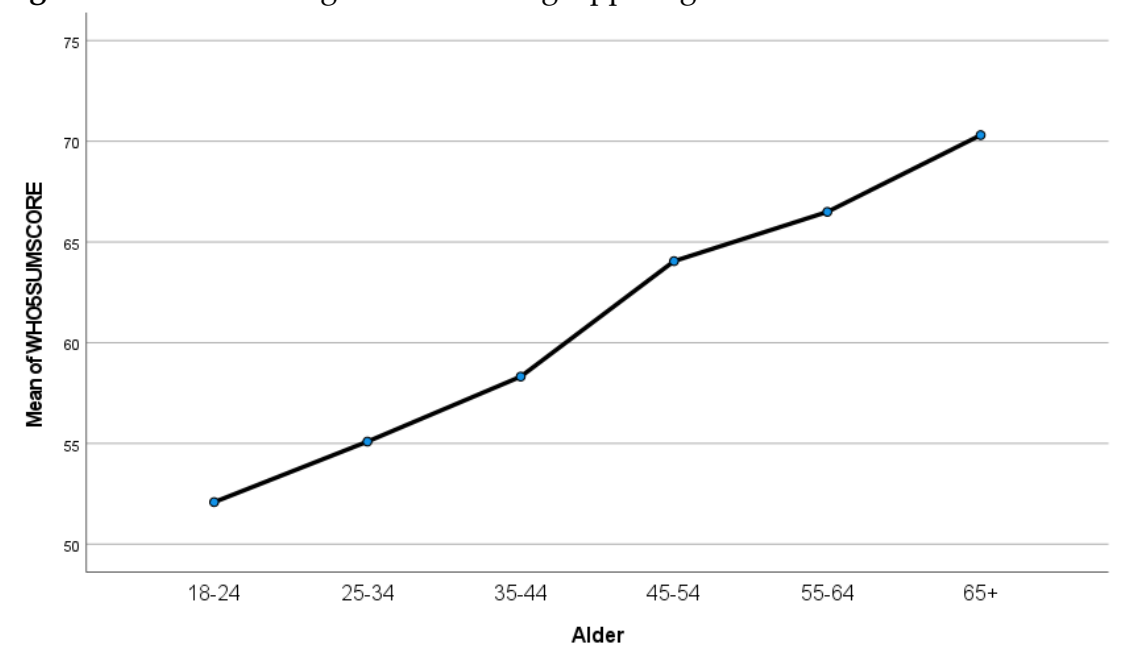

Udsvinget mellem yngste aldersgruppe (point 52,1) og ældste aldersgruppe (point 70,3 ) er hele 18,2 point, svarende til næsten en femtedel af hele skalaen 0-100. Forskellen mellem aldersgrupperne er højsignifikant $(\mathrm{p}<.001)$. Det skal bemærkes, at de yngste grupper i gennemsnit er meget tæt på den af sundhedsstyrelsen angivne første røde lampe på 50 point, men ikke mindst skal det også bemærkes, at den ældste aldersgruppe (65+) befinder sig et lille stykke over den samlede danske norm for trivsel. De ældste kan altså som en samlet gruppe synes ganske uberørte, hvad angår trivsel (70,3 mod normen 68). Dette til trods for, at personer over 80 år generelt skulle score lavest og således trække gennemsnittet ned.

Ser vi på den andel, der mistrives i forhold til Sundhedsstyrelsens normer, gælder det, at hele 29 procent af respondenterne scorer under 50, hvor der som nævint er angivet risiko for depression eller stressbelastning. Af disse scorer de 12 procent under 35 point, hvor der er angivet stor risiko for depression eller stressbelastning. Kønsfordeler vi disse tal for hvor mange, der synes stærkt negativt påvirket alene i de stærkest belastede unge aldersgrupper, fremkommer tabel 5.6. 
Tabel 5.6. Andel af personer, der er i risiko eller stor risiko for depression eller langvarig stressbelastning ifølge Sundhedsstyrelsens normer.

\begin{tabular}{lllll}
\hline WHO5 & $\begin{array}{l}\text { Alder 18-24 } \\
\text { Kvinder }\end{array}$ & $\begin{array}{l}\text { Alder 18-24 } \\
\text { Mænd }\end{array}$ & $\begin{array}{l}\text { Alle } \\
\text { Kvinder }\end{array}$ & $\begin{array}{l}\text { Alle } \\
\text { Mænd }\end{array}$ \\
\hline I risiko $<50$ point & $50 \%$ & $47 \%$ & $32 \%$ & $25 \%$ \\
I stor risiko $<35$ point & $24 \%$ & $15 \%$ & $15 \%$ & $10 \%$ \\
\hline
\end{tabular}

Tallene viser tydeligt, at det især er kvinderne og ganske særligt den yngste aldersgruppe, der er negativt påvirket på trivslen. Blandt de unge kvinder er det hele 24 procent, der ifølge normerne tilskrives at være i stor risiko for at befinde sig i en depression eller langvarig stresstilstand. De danske normer er skabt i tider uden COVID-19, og tallene synes at pege på en selvstændig og ganske alvorlig ramt undergruppe af danskere. Undersøgelsen her peger på, at en ganske stor andel af de unge kvinder har oplevet alvorlig mistrivsel under COVID-19-krisens store nedlukning i foråret 2020.

\section{Korrelationer mellem helbred og trivselsmål}

Denne undersøgelse har vist, at 2/3 af danskerne er bekymrede over, at de selv ellers deres nærmeste skal blive smittet, og at denne bekymring er stigende med alderen. Undersøgelsen har også påvist, at det fysiske helbred tilsyneladende ikke har ændret sig under nedlukningen, mens det psykiske helbred, trivslen, synes temmelig negativ påvirket. Her er det især de unge, der mistrives, mens de ældre synes ganske upåvirkede. En tværsnitsundersøgelse som denne vil ikke kunne påvise direkte årsagssammenhænge og eksempelvis konkludere, at det er på grund af Corona-truslen eller nedlukningen, at trivslen er dalet. Videnskabeligt set kan kun konstateres, at der optræder en samtidighed. Det kan for eksempel synes mærkeligt, at det er den ældre gruppe, der trives bedst samtidig med, at det er den ældre gruppe, der er mest bekymret for smitte. Smittefrygt og trivsel hænger tilsyneladende ikke sammen, når man ser på rå gennemsnit. For at belyse dette nærmere kan man korrelere de her nævnte mål med hinanden. Er det de samme personer, som scorer højt på smittefrygt, der har det fysisk og psykisk dårligt? (Tab. 5.7).

Tabel 5.7. Korrelationer (r) mellem bekymring for smitte, selvvurderet helbred og WHO5

\begin{tabular}{llll}
\hline & Smittebekymring & Fysisk helbred & Psykisk trivsel \\
\hline Smittebekymring & 1 & 0.02 & $-0.16^{* * *}$ \\
Selvvurderet (/fysisk) helbred & & 1 & -0.05 \\
(Psykisk) trivsel WHO5 & & 1 \\
\hline
\end{tabular}

Som det kan ses i tabellen, er der ingen signifikant korrelation mellem selvvurderet (fysisk) helbred og de to andre mål, hvilket er logisk, da det fysiske helbred ikke synes påvirket under Corona-nedlukningen. Derimod ses en signifikant korrelation på .16 
mellem bekymring for smitte og den psykiske trivsel. Dem, der er bekymrede for smitte, er også dem, der i højere grad mistrives. Dette synes også logisk, da de to mål ikke kan siges at være helt uafhængige af hinanden. Men denne korrelation giver til gengæld et kraftigt fingerpeg om, at den nedsatte trivsel faktisk har en relation til Corona, og at der via bekymringen kan sandsynliggøres en årsagssammenhæng mellem Corona-tiden og mistrivslen. Denne sammenhæng er stærkere end det fund, at det er de ældre aldersgrupper, der både er mest bekymrede og samtidig trives bedst.

\section{Diskussion}

Det er overordnet fundet, at respondenterne på indsamlingstidspunktet, der lå lige efter den store nedlukning i foråret 2020, antalsmæssigt selv har været Corona-syge på et så lille niveau, at der ikke kan laves meningsfuld statistik på det. Frygten for, at man selv og nærtstående andre vil blive smittet er til gengæld udbredt, omkring 2/3 af befolkningen frygter personligt smitte. Det er mest kvinderne og det er helt tydelig mest de ældre, der bekymrer sig om smitte.

Kvinder er generelt mere bekymrede for personlige og familiære anliggender end mænd (van der Vegt \& Kleinberg 2020), og kønsforskellen omkring Coronasmitte synes ikke at kalde på specifikke overvejelser. Det kendes imidlertid ikke fra andre studier, at bekymringer for smitte stiger stærkt med alderen; men dette fund synes i tråd med et nyligt israelsk COVID-19-studie, der finder, at Coronakrisen medfører øget “oplevet stress" med alderen (Horesh, Kapel Lev-Ari \& Hasson-Ohayon 2020). Som tidligere nævnt kan dette vel bedst betragtes som en naturlig følge af myndighedernes oplysninger og betoninger af, at Corona er en farlig og potentielt dødelig sygdom for de ældre, og dem der i forvejen er svækkede.

Det selvvurderede fysiske helbred synes ganske upåvirket på indsamlingstidspunktet, hvilket heller ikke kan komme overraskende. Corona beskrives ganske vist som en helbredstrussel med mulighed for alvorlig sygdom og død; men da de faktiske tal for antallet af alvorligt syge og smittede er ganske små, kan det slet ikke forventes at kunne slå igennem $\mathrm{i}$ tal for den generelle befolkning. Her er der noget kontraintuitivt meldt om færre dødsfald i foråret 2020 end årene før, ${ }^{1}$ hvilket formentlig skyldes, at den almindelige influenza-virus også har haft ringe mulighed for at smitte under nedlukningen, hvor smittevejene for almindelige virus også blev begrænset.

Den psykiske trivsel har i denne undersøgelse vist sig at være generelt nedsat i indsamlingsperioden. Tallene viser store forskelle, hvor nogle grupper er ramt hårdt på trivslen, især de yngre kvinder, mens andre grupper - folk over 65 år - tilsyneladende ikke er ramt overhovedet, når man ser på gruppen som en helhed.

Talforskellene mellem grupperne er ret markante, og der er grund til at antage, at COVID-19-krisen har ramt befolkningen skævt på trivslen. Skole-nedlukningerne synes at have haft større konsekvenser end nedlukningen af arbejdspladser, og dette forhold synes at kunne give empirisk belæg for de betragtninger, den norske sundhedsminister Bent Høie gjorde sig i en berømt TV-transmitteret tale 27. april 
2020. Her gav han udtryk for, at ungdommen har givet de største ofre under COVID19 i foråret 2020 i forhold til øvrige aldersgrupper. ${ }^{2}$ Han sagde bl.a., at "næste sommer findes ikke, når du er ung," fordi næste sommer ikke er en erfaringsbaseret begivenhed som for de midaldrende, men en engangsoplevelse for de unge, fordi hvert forår og sommer byder på noget enestående nyt; noget gammelt afsluttes, og der er glade forventninger til det kommende nye, der vil begynde. Eksamen afsluttes, hvilket betyder åbning af nye livskapitler. Der vil komme fester, hvor forholdet til det modsatte køn udforskes, og partnere skal træffes, og mange slags forhold skal erfares. Alt dette blev aflyst, og det er naturligvis en voldsom indgriben i et ungt menneskes oplevede livsudfoldelse. Forventningerne til fremtiden ser også anderledes ud for de unge, fordi realistiske planer for det fremtidige liv bliver sat i parentes og bliver usikre. Den store internationale verden, der før lå for at skulle opleves og udforskes, blev pludselig utilgængelig med rejseforbuddet. Det er ikke underligt, at dette har ført til større mismod for de unge. Det synes heller ikke meget underligt, at kvinderne er hårdest ramt på trivslen, hvis det stadig står til troende, at kvindernes sociale bånd er mere rettet mod det støttende, omsorgsorienterede og følelsesrelaterede, som det blev konstateret i en nu 30 år gammel undersøgelse (Flaherty \& Richman 1989). Med dette følger også større sociale afsavn for kvinderne end for mændene.

En tilsvarende undersøgelse som vores, foretaget parallelt under COVID-19-nedlukningen i Italien, finder lignende resultater som de her fremlagte (Prati 2020). Den italienske undersøgelse har $\mathrm{N}=1569$, men indsamlingen er foregået som "convenient sample", dvs. usystematisk indsamlede data over nettet. Respondenterne kan således ikke angives som repræsentative for befolkningen; men til gengæld er den italienske undersøgelses mål for mentalt helbred mere sofistikerede, idet der måles med skalaerne: Mental Health Continuum-Short Form og Mental Health Continuum -Short Form, det vil sige skalaer, hvor respondenterne spørges til hyppigheden af egentlige psykiske symptomer. Den italienske undersøgelse finder, at risikofaktorerne for laveste mentale helbred er: lavere alder, kvindeligt køn og højere bekymringstendens, fuldstændig som det også er fundet i herværende undersøgelse. Derudover finder italienerne øget risiko for dårligt mentalt helbred ved arbejdsløshed, lav medie-adgang, lav coping-effektivitet, lav tillid til institutioner og negativ attitude mod restriktionerne - alt sammen variable, der ikke er målt i herværende undersøgelse, men som bidrager til billedet af, at Corona-nedlukningen har ramt befolkningen skævt.

Trivselsmålet WHO5 angiver cut-off-scores for "risiko" eller "alvorlig risiko for depression eller langvarig stress", og skal disse betegnelser tages for pålydende, skulle altså 24 procent af landets kvinder mellem 18-24 år skrives op til en lægesamtale med vurdering af den mentale sundhed og stillingtagen til sygemelding og/eller medikamentel behandling. Så galt synes det dog alligevel ikke at stå til, og forskellene på en screenings-undersøgelse og en egentlig diagnostik af depression kommer til syne med al tydelighed. Vi skal naturligvis ikke til at sætte hver fjerde unge kvinde på antidepressiva. På den anden side kan tallene måske minde os om, at netop denne

2 https://tv2-dk-clips.secure.footprint.net/vod/flex/33f31bd9-4ffb-4c0e-b7ab-8a9501f24c77.mp4. 
gruppe i forvejen er kendt som mentalt mistrivende. I en opgørelse fra 2017 skriver Sundhedsstyrelsen, at det mentale helbred er forværret gennem de sidste 7 år, og at det netop er gruppen af kvinder mellem 18 og 24 år, der angiver det værste mentale helbred, målt med skalaen SF-12 (Sundhedsstyrelsen 2017). Corona-nedlukningerne synes på denne måde at anskueliggøre Mattheus-effektens forudsigelse af, at fra de fattige skal endog det fratages, som de har. Det er de i forvejen truede, der afgiver mest trivsel.

Et paradoksalt forhold skal nævnes som det sidste: At de ældre over 65 år tilsyneladende scorer allerhøjest på trivselsmålet, selvom det også er dem, der er mest bekymrede for smitte. Dette fund bekræftes imidlertid også af den ovennævnte israelske undersøgelse (Horesh et al. 2020), hvor man finder svagt forøget stress hos de ældre (svarende til mere smittefrygt), men samtidig finder, at livskvaliteten er signifikant større hos de ældre. Dette paradoks kan måske pege på, at god trivsel og sygdomsbekymring til trods for deres umiddelbare modsætningsforhold ikke nødvendigvis ligger som yderpunkter på samme skala, og at trivsel kan være langt mere bundet til andre forhold som for eksempel mening i livet. Disse forhold vil diskuteres yderligere i næste artikel.

\section{Konklusion}

Næsten ingen har været personligt syge af Corona foråret 2020 i en tværsnitsundersøgelse som denne. 2/3 af danskerne er bekymrede over, at de selv eller deres nærmeste skal blive smittede med Corona, størst bekymring ses hos mest kvinder og de ældre over 65 år. Det selvvurderede fysiske helbred har ikke ændret sig. Den selvrapporterede trivsel har generelt vist en større tilbagegang, og tilbagegangen har ramt skævt i befolkningen. De helt unge og særligt de unge kvinder har største nedgang i trivsel, og trivslen er for en større del af disse alarmerende lav.

\section{LITTERATUR}

Flaherty, Joseph \& Judith Richman

1989 "Gender differences in the perception and utilization of social support: Theoretical perspectives and an empirical test", Social Science and Medicine 28(12), 1221-1228. https://doi.org/10.1016/0277-9536(89)90340-7

Prati, Gabrielle

2020 "Mental Health and Its Psychosocial Predictors during National Quarantine in Italy against the Corona Virus Disease 2019 (COVID-19)", https://doi.org/10.31234/osf.io/4ar8z

Horesh, Danny \& Rony Kapel Lev-Ari \& Ilanit Hasson-Ohayon

2020 "Risk factors for psychological distress during the COVID-19 pandemic in Israel: Loneliness, age, gender, and health status play an important role", British Journal of Health Psychology. https://doi.org/10.1111/bjhp.12455

Koenig, Harold G. \& Dana E. King \& Verna B. Carson

2012 Handbook of religion and health, Oxford University Press.

Sundhedsstyrelsen

2017 Den nationale sundhedsprofil (2017), https://www.sst.dk/-/media/Udgivelser/2018/Den-Nationale- 
Sundhedsprofil-2017.ashx?la=da\&hash=421C482AEDC718D3B4846FC5E2B0EED2725AF517

Udateret Sundhedsstyrelsens guide til trivselsindekset WHO5:

https://www.regionsjaelland.dk/Kampagner/broen-til-bedre-

sundhed/Materialer/PublishingImages/WHO5\%20skema.pdf

Vegt, Isabelle van der \& Bennett Kleinberg

2020 "Women worry about family, men about the economy: Gender differences in emotional responses to COVID-19", Lecture Notes in Computer Science Vol. 12467 LNCS, pp. 397-409. https://doi.org/10.1007/978-3-030-60975-7_29

Peter la Cour, lektor, ph.d., specialist $i$ sundhedspsykologi Institut for psykologi, Københavns Universitet

Heidi Frølund Pedersen, ph.d, seniorforsker og psykolog

Funktionelle Lidelser, Aarhus Universitetshospital 